\title{
Stimulating innovative activity as a tool for ensuring strategic development of motor transport enterprises
}

\author{
Olena G. Parfentieva ${ }^{a^{*}}$, Pavlo Yu. Grechan ${ }^{\mathrm{b}}$ and Alla P. Grechan ${ }^{\mathrm{a}}$
}

${ }^{a}$ The Department of Economics, Faculty of Economics and Law, National Transport University, Ukraine ${ }^{b}$ Department of Management, Faculty of Management, Logistics and Tourism, National Transport University, Ukraine

\section{CH R O I C L E ABSTRACT}

\begin{tabular}{l} 
Article history: \\
Received: April 18, 2019 \\
Received in revised format: April \\
282019 \\
Accepted: May 20, 2019 \\
Available online: \\
May 20, 2019 \\
\hline Keywords: \\
Motor transport enterprises \\
Innovative activity \\
Stimulation of innovative activity \\
Strategic development \\
Transport
\end{tabular}

\section{Introduction}

The transport industry is one of the keys for the economies of the countries. The role of transportation in the national economic system is very multifaceted, being, like other sectors of the economy, a source of taxes to state and local budgets, a significant employer, forming a certain demand for investment and other types of resources, as well as being a key component of the tertiary sector of the country's economy (services industry), the transportation industry, while being at the same time the basis for the development of industry, agriculture and service sector, linking numerous producers and buyers of products (works, services), allowing them to form optimal logistics between them (European Commission, 2011). It is worth noting the growing role of transportation in the context of the transition of the majority of economically developed countries to the post-industrial model of building their economies, where the service sector to which the transportation industry belongs is dominant (Aggelakakis et al., 2015). In this context,

* Corresponding author.

E-mail address: alenagp@ukr.net (O. G. Parfentieva)

(C) 2019 by the authors; licensee Growing Science, Canada doi: $10.5267 /$ j.msl.2019.5.022 
we note the increasing attention to the problems of the development of the transportation industry in developing countries (Leinbach, 1995; Zohrehvandi \& Ghazanfari, 2013; Adanikin \& Oyedepo, 2017), where a special place is occupied by states that were part of the USSR, such as Ukraine, Russia, Belarus, Kazakhstan (Thor, 2013; Tkachev, 2017; Sukhonos, 2012; Kim, 2016). We note that in these countries, the identification of problems in the functioning of the transport industry and the search for ways of its strategic development is a gateway to increase their competitiveness, maximize the realization of their potential for economic growth and improve the quality of life of the population.

Considering the monopolistic position of the state in terms of the development of railway and pipeline transportation, the complexity of functioning of the water and air transportation, we note the increasing role of motor transportion in these countries (Chuvaev, 2013; Faylert, 2016), which leads to an increase in the number of studies in this scientific field, which focus on the search and optimization of ways for the strategic development of motor transport enterprises (Zheleznyak, 2012; Tsymbal, 2014; Toymentseva, 2012; Kulakova et al., 2018). We note that the issues of strategic development of transport enterprises, including motor transport, are actively covered not only by scholars from the said countries, here we can mention the developments of Borgström et al. (2017), Pettigrew et al. (2002), Loo and Tsoi (2018). The strategic development of motor transport enterprises includes addressing the issues of their competitiveness in the domestic and foreign markets of motor transport services, based on stimulating the development, purchase and introduction of innovations (Aggelakakis et al., 2015). Thus, we can say that the innovative activity of motor transport enterprises is one of the important tools to ensure their competitiveness and strategic development. At the same time, scientific research on the innovative activity of transport enterprises, including road carriers in developing countries that were part of the USSR (Luzhetskyy, 2016; Halunko et al., 2018; Synytsia, 2015) indicate significant problems and the need to find ways to optimize the stimulation of such activity in these countries regarding a selected group of enterprises in the context of ensuring their effective strategic development, which is the objective of our study. Critical assessment of existing scientific developments on the issues of stimulating innovation activity in the framework of ensuring the strategic development of transport (road transport) enterprises (Aggelakakis et al., 2015; Lendel et al., 2015; Moen, 2016; Wiesenthal et al., 2011; Condeço-Melhorado et al., 2013; Luzhetskyy, 2016; Halunko et al., 2018) allows pointing out that:

- the developments of scholars from economically developed countries require adaptation to the realities of functioning of both the economy and its transport industry in developing countries that were part of the USSR;

- scientific studies of scholars from the countries selected for research mainly concern a single country and do not summarize the problems across all countries;

- there is a need to adapt foreign experience to one of the selected countries and to find new ways to stimulate innovative activity in the context of ensuring the effective strategic development of motor transport enterprises in this country.

The above confirms the correctness of the choice of the research objective.

Based on the research objective, it is important to prove or challenge a number of hypotheses, namely:

- the transport industry and its motor transport sector are key for the countries of the post-Soviet economic space and develop in the same direction;

- the strategic development of motor transport enterprises depends on their innovative activity;

- a significant number of problems in stimulating innovative activity hinder both innovative activity and the effective strategic development of motor transport enterprises in Ukraine, Russia, Belarus and Kazakhstan;

- motor transport enterprises in the key countries of the post-Soviet economic space, in ensuring their strategic development, need to develop and implement ways to optimize the stimulation of their innovation activity. 


\section{Materials and Methods}

To achieve the objective of the research paper, a system of general scientific research methods at the empirical and theoretical levels was used, namely: a comparison method for assessing the innovative activity of motor transport enterprises in key countries of the post-Soviet economic space; methods of analysis and synthesis for identifying problems of strategic development and innovative activity of motor transport enterprises of Ukraine, Russia, Belarus and Kazakhstan; an abstraction method for identifying development trends, including in the field of innovation, transport and motor transport in the countries selected for the study; induction and deduction methods to develop ways to optimize the stimulation of innovative activity of Ukrainian, Russian, Belarusian, and Kazakhstani motor transport enterprises in ensuring their strategic development; methods of systematization, grouping, logical generalization for systematization of information, drawing conclusions and scientific proposals of the research paper. The research methodology is based on a historical and systemic approach to discovering and solving the problems of stimulating innovative activity of motor transport enterprises in Ukraine, Russia, Belarus and Kazakhstan in ensuring the strategic development of these business entities. In this work, innovative activity is presented as one of the main tools for ensuring the strategic development of motor transport enterprises in key countries of the post-Soviet economic space. The study is also based on the assumption that it is the problems of stimulating innovative activity that are one of the obstacles to the effective strategic development of Ukrainian, Russian, Belarusian, Kazakhstan motor transport enterprises and adversely affect the competitiveness of these business entities in the domestic and foreign markets for motor transport services.

\section{Results}

3.1. Development of the transport industry and its motor transport sector in the countries of the postsoviet economic space

The transport industry, like the entire economic system of the post-Soviet countries, has gone through a period of profound transformation, under the active influence of the crisis phenomena in the development of national economies at the same time, both during the transition from controlled to market economy and during the response of national economies to crises in the world economic system.

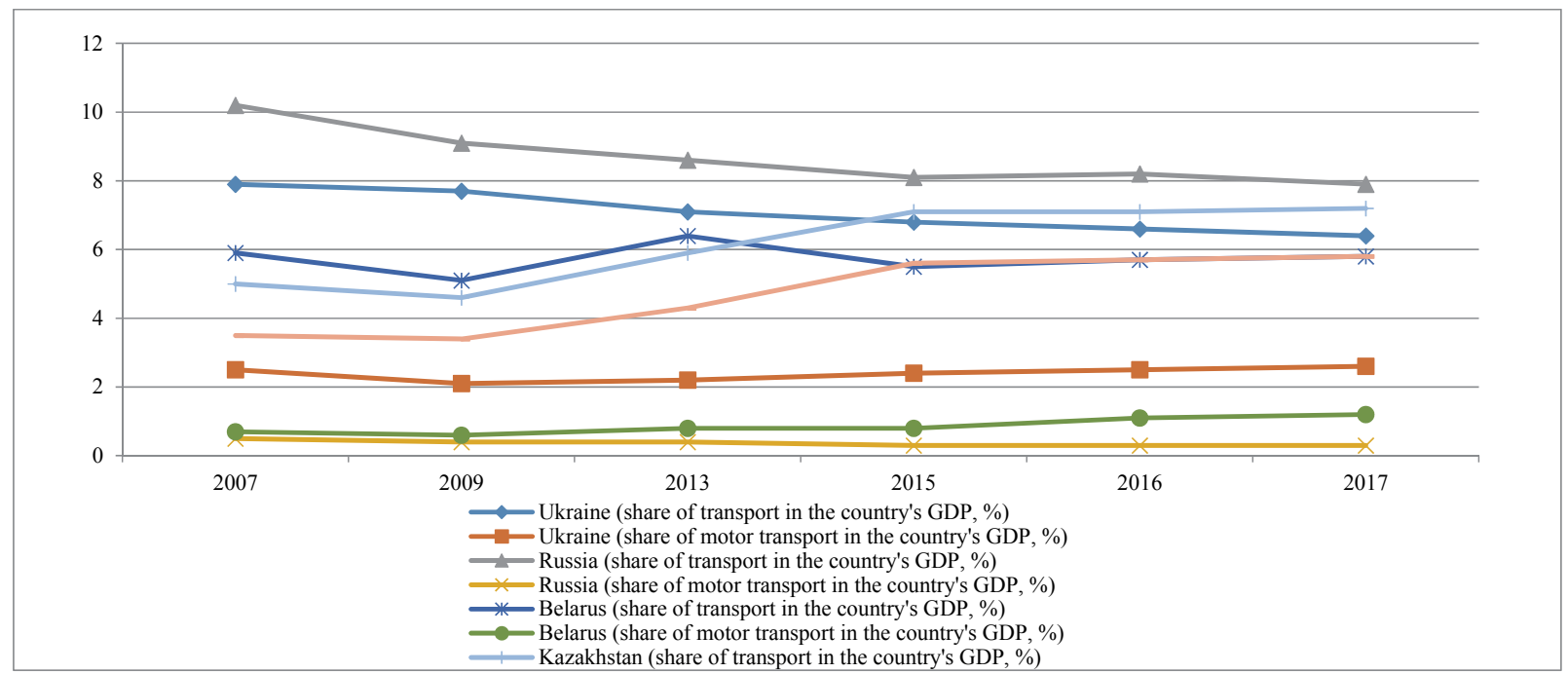

Fig.1. Dynamics of the share of the transport industry and its motor transport sector in the GDP of key countries in the post-Soviet economic space in 2007-2017

*- Compiled by the author on the basis of State Statistics Service of Ukraine (2019), Federal State Statistics Service of the Russian Federation (2019), National Statistical Committee of the Republic of Belarus (2019), Committee on Statistics of the Republic of Kazakhstan (2019)

Thus, it is important to study the dynamics of the share of transportation industry and its motor transport sector in the GDP of key countries in the post-Soviet economic space (Ukraine, Russia, Kazakhstan, 
Belarus) from 2007 to 2017 and consider the impact of two consecutive economic crises 2008-2009 and 2014-2015 on their development (Fig. 1). We note that for convenience of research we take: 2007, as the last pre-crisis year; 2009, as the year of the end of the first crisis; 2013, as the pre-crisis year; 2015, as the year of the end of the second crisis; 2016 - 2017, as the last years of statistical studies in the countries selected for evaluation.

A study of the development of the transport sectors of the countries of the post-Soviet economic space based on an assessment of their share in the GDP of these countries allows, on the one hand, indicating a significant role of transportation in the economies of Ukraine, Russia, Belarus and Kazakhstan (at least $5 \%$ of GDP during the entire study period), and on the other - the trends of different directions in the development of transportation in the countries selected for evaluation, where, against the background of a constant decline in the volume of transport services in Ukraine (-1.5\% of GDP over the study period) and the Russian Federation (-2.3\% of GDP for 2007-2017) there is a successful recovery of the industry in Belarus $(-0.1 \%$ of GDP over the study period), as well as significant growth in Kazakhstan $(+2.2 \%$ of GDP for 2007-2017).

Regarding motor transport, the trends in all countries except Russia (- $-0.2 \%$ of GDP over the study period) are positive: Ukraine ( $+0.1 \%$ of GDP for $2007-2017)$; Belarus $(+0.5 \%$ of GDP for the study period); Kazakhstan $(+2.3 \%$ for 2007-2017). A significant role of motor transport in the economies of Ukraine (2.6\% of GDP at the end of 2017) and Kazakhstan (+ 5.8\% of GDP at the end of 2017) and insignificant in the Russian Federation (0.3\% of GDP at the end of 2017) should separately be noted. Regarding Belarus, we can point to the average value of the share of the motor transport sector in the national economy (1.2\% of GDP at the end of 2017).

Essential for the study is the assessment of the share of motor transport enterprises in revenues generated by transport industry of Ukraine, Russia, Belarus and Kazakhstan in 2007-2017 (Fig. 2).

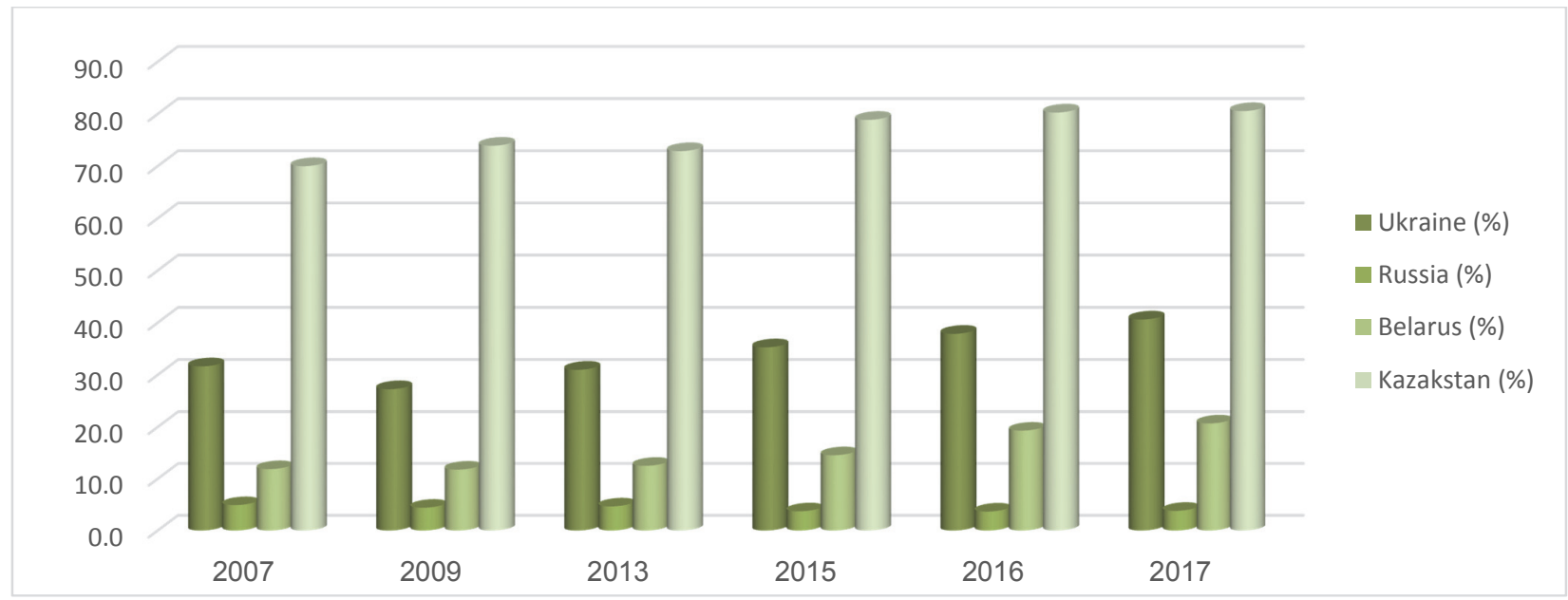

Fig. 2. Dynamics of the share of the motor transport sector in the revenues of the transport industries of key countries of the post-Soviet economic space in 2007-2017

*- Compiled by the author on the basis of State Statistics Service of Ukraine (2019), Federal State Statistics Service of the Russian Federation (2019), National Statistical Committee of the Republic of Belarus (2019), Committee on Statistics of the Republic of Kazakhstan (2019)

A study of the role of motor transport in the transportation industry of Ukraine, Russia, Belarus and Kazakhstan points to:

- a key role of motor transport in the transport industry of Ukraine with an increase in its share in the country's transport revenues since $2009(+9.0 \%$ in total industry revenues over the study period and + $13.3 \%$ in industry total revenue for 2009-2017);

- a minor role of motor vehicles in the transportation sector of Russia with a decrease in its share in the 
revenues of the entire transport industry of the state over the study period $(-1.1 \%$ in the total revenues of the industry);

- a significant role of automobile enterprises in the generation of transportation revenues in Belarus $(+$ $8.8 \%$ in total industry revenues over the study period) and the rapid restoration of road transportation enterprises after the crisis of 2008-2009;

- a fundamental role of motor transport in the transportation industry of Kazakhstan with and increase in its share in the revenues of the state's transportation industry during the study period $(+10.6 \%$ to $80.6 \%$ at the end of 2017).

The study of the development of the transportation industry and its motor transport sector in the countries of the post-Soviet economic space requires an assessment of the dynamics of the share of employed in this industry and its sector to the total number of people employed in the economies of Ukraine, Russia, Belarus and Kazakhstan in 2007-2017 (Fig. 3).

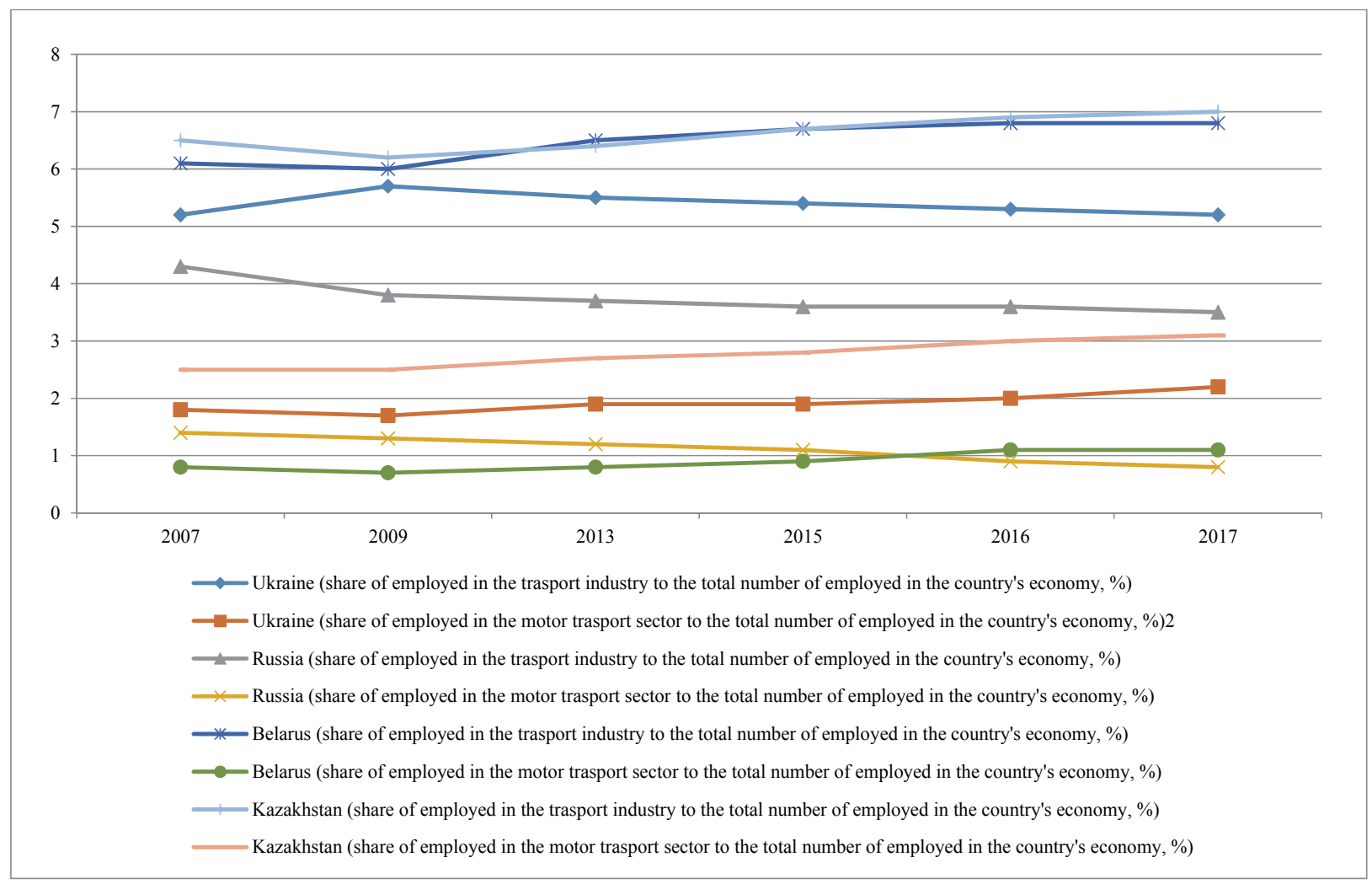

Fig. 3. Dynamics of the share of employed in the transport industry and its motor transport sector in the total number of employed in key countries of the post-Soviet economic space in 2007-2017

*- Compiled by the author on the basis of State Statistics Service of Ukraine (2019), Federal State Statistics Service of the Russian Federation (2019), National Statistical Committee of the Republic of Belarus (2019), Committee on Statistics of the Republic of Kazakhstan (2019)

The study of the role of the transport industry and its motor transport sector in the labor market of Ukraine, Russia, Belarus and Kazakhstan revealed codirectional trends with the role of transport in the economies of selected countries, namely:

- the transport sector provided the entire study period with more than $5 \%$ of the employed in Ukraine (5.2\% of the employed at the end of 2017), Belarus (6.8\% of the employed at the end of 2017), Kazakhstan (7\% of the employed at the end 2017). The only exception was the Russian Federation with a share of the employed in transport which did not exceed $4.5 \%$ of the total employed of the country $(3.5 \%$ of 
the employed at the end of 2017);

- there was an increase in the share of employed in the transportation industry to the total number of employed in 2007-2017 in Belarus (+0.7) and Kazakhstan (+0.5\%), against the background of an unchanged share in Ukraine and its decline in Russia (-0.8\%);

- the share of employed in motor transport enterprises, as well as its dynamics over the study period, differed significantly in the key countries of the post-Soviet economic space in the period from 2007 to 2017. Thus, in Ukraine there was an increase in the share of employed in motor transport sector $(+0.4 \%$ to $2.2 \%$ of the total number of employed in the country at the end of 2017), the same can be noted in Belarus $(+0.3 \%$ to $1.1 \%$ of the total number of employed in the country at the end of 2017$)$ and Kazakhstan $(+0.6 \%$ to $3.1 \%$ of the total number of employed in the country at the end of 2017). Regarding Russia, we note a decline in the share of people employed in motor transport enterprises $(-0.6 \%$ to $0.8 \%$ of the total number of employed in the country at the end of 2017).

World practice shows that the predominant number of motor transportation companies belong to small and medium-sized businesses, while large enterprises dominate in other types of transportation (Aggelakakis et al., 2015; European Commission, 2012). This requires consideration of the dynamics of the share of small and medium-sized businesses (SMEs) in the total number of motor transport enterprises in Ukraine, Russia, Belarus and Kazakhstan during the study period (Fig. 4).

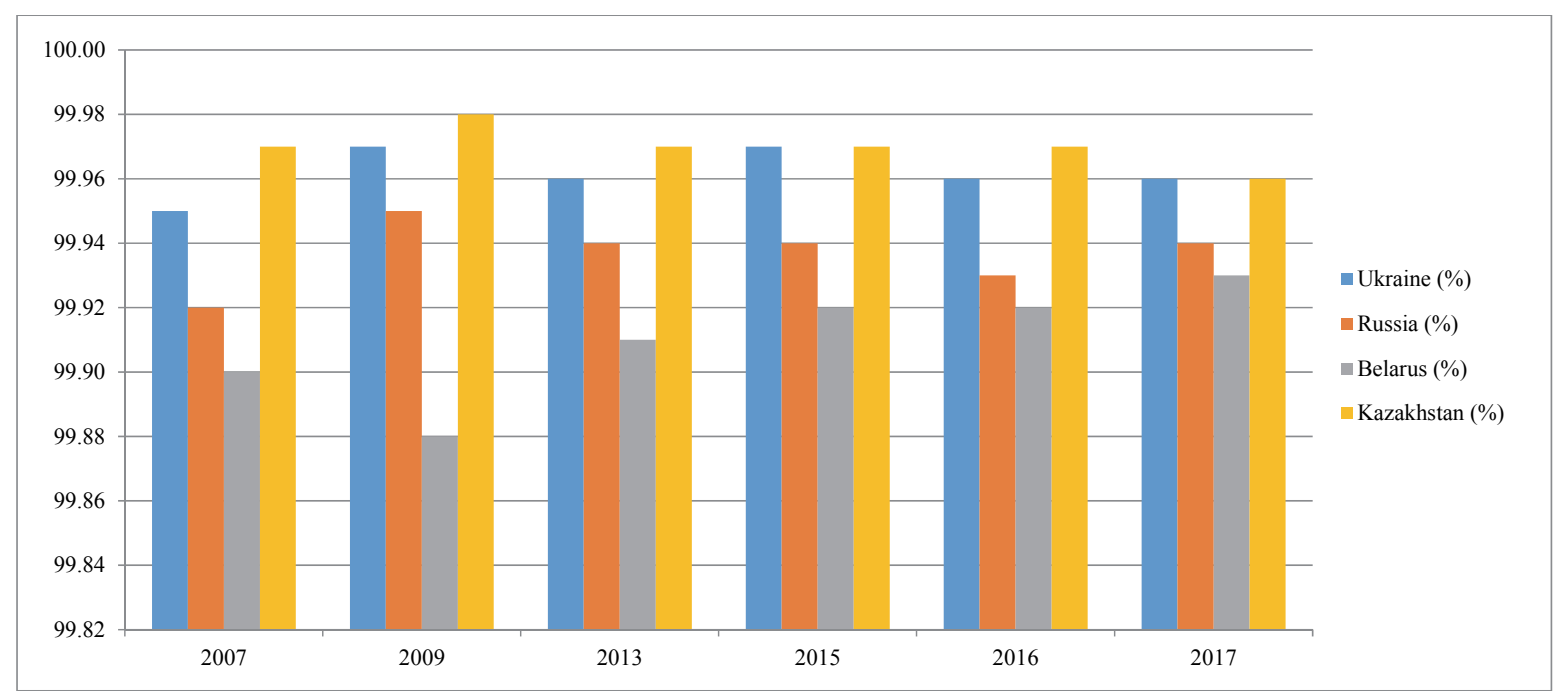

Fig. 4. Dynamics of the share of SMEs in the total number of motor transport enterprises in key countries of the post-Soviet economic space in 2007-2017

*- Compiled by the author on the basis of State Statistics Service of Ukraine (2019), Federal State Statistics Service of the Russian Federation (2019), National Statistical Committee of the Republic of Belarus (2019), Committee on Statistics of the Republic of Kazakhstan (2019)

Research on the dynamics of the share of small and medium-sized enterprises in the total number of motor transport enterprises in Ukraine, Russia, Belarus and Kazakhstan in 2007-2017 confirmed global trends, since the share of large enterprises in this sector of the transport industry in each of the selected countries is accounted for no more than $0.1 \%$ of all motor transport enterprises. At the same time, the share of large enterprises in Belarus and the Russian Federation was more than in Ukraine and Kazakhstan due to a significant number of such enterprises of the state and municipal ownership.

Exploring the development of transport, as well as motor transport companies, we note high competition in both domestic and foreign markets of such services in selected countries, which means finding ways to improve competitiveness, which is impossible without ensuring innovation-based strategic development. 


\subsection{The relationship of strategic development and innovative activity in motor transport enterprises}

The motor transport sector can be attributed to the mature and fragmented sectors of the country's economy, which is reflected in the following characteristics: low barriers of entry to the industry; direct communication of service providers with end users; a large proportion of small and medium enterprises; high competition with an emphasis on price and quality of services; lack of enterprises with high market power; insignificant financial reserves of business entities; difficulties in inventing new products and launching them in the market (Borgström et al., 2017; Porter, 1997).

These characteristics can be fully applied to the motor transport sectors of the transport industries of the key countries of the post-Soviet economic space.

Under these conditions, motor transport enterprises should direct all efforts towards ensuring and improving their competitiveness, which requires the implementation of strategic management, including in the elaboration of development strategies, which include the following strategies: the development of strong competitive sides; leveling weaknesses; capture of vacant niches; specialization; growth through merging and acquisitions; exceptional differentiation (Zheleznyak, 2012).

Thus, strategic development is the dominant aspect of the effective financial and economic activities of motor transport enterprises in the modern conditions of the transport services market and national economies of the world, including those that are among the key countries of the post-Soviet economic space. On this basis, it is necessary to show a graphic interpretation of the formation and maintenance of the strategic development of a motor transport enterprise (Fig. 5).

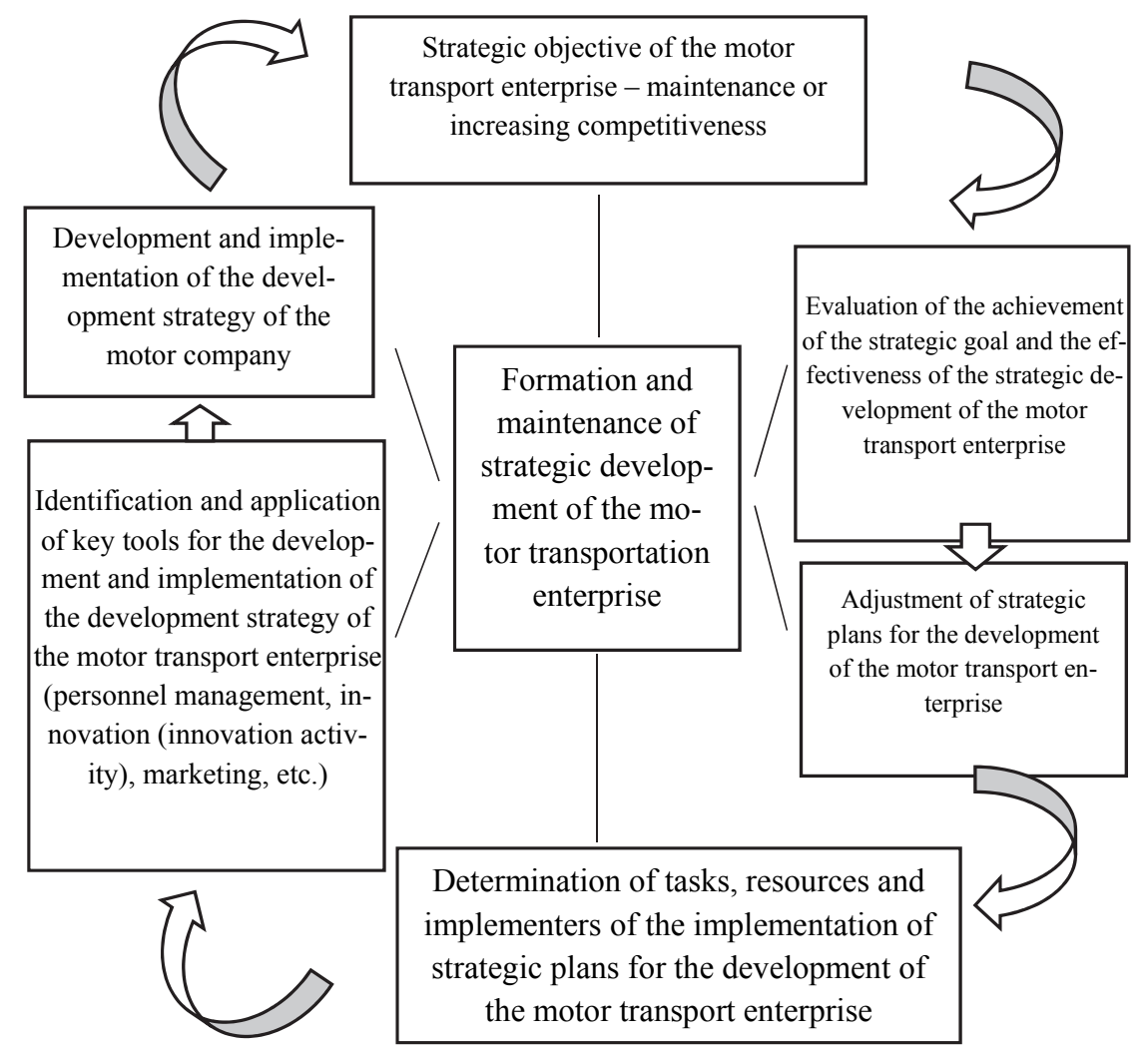

Fig. 5. Graphic interpretation of the formation and maintenance of the strategic development of the moSource: compiled by the author tor transport enterprise

Based on the developed graphical interpretation, it is possible to reveal a clear relationship between the strategic development of a motor transport enterprise and its innovative activity. We note that innovation activity is one of the key tools for developing and ensuring the implementation of development strategies 
for motor transport enterprises. At the same time, the innovation activity of an enterprise should be understood as a set of measures for the development, sale, purchase, and introduction of innovations within the business entity's financial and economic activities in order to increase its competitiveness in domestic and foreign markets (Lendel et al., 2015; OECD, 2019).

We note significant problems with the innovation activity of enterprises in the countries selected for the study, including those existing in the motor transport enterprises (Table 1).

\section{Table 1}

Dynamics of the share of enterprises that developed and implemented innovations in key countries of the post-Soviet economic space in 2007-2017 (including motor transport enterprises)

\begin{tabular}{cccccccc}
\hline Country & $\mathbf{2 0 0 7}$ & $\mathbf{2 0 0 9}$ & $\mathbf{2 0 1 3}$ & $\mathbf{2 0 1 5}$ & $\mathbf{2 0 1 6}$ & $\mathbf{2 0 1 7}$ & Deviation \\
\hline Ukraine (developers), \% & 14.2 & 12.8 & 16.8 & 17.3 & 18.9 & 16.2 & 2 \\
\hline Including motor transport,\% & 11.4 & 10.5 & 9.7 & 9.5 & 9.2 & 9.1 & -2.3 \\
Ukraine (implemented),\% & 11.5 & 10.7 & 13.6 & 15.2 & 16.6 & 14.3 & 2.8 \\
Including motor transport,\% & 10.2 & 9.9 & 9.5 & 8.9 & 8.8 & 8.6 & -1.6 \\
Russia (developers),\% & 9.4 & 9.4 & 9.7 & 9.5 & 9.4 & 9.3 & -0.1 \\
Including motor transport,\% & 7.6 & 7.0 & 6.9 & 6.8 & 6.8 & 6.4 & -1.2 \\
Russia (implemented),\% & 11.2 & 10.1 & 10.3 & 9.5 & 9.4 & 9.3 & -1.9 \\
Including motor transport,\% & 9.6 & 9.2 & 8.8 & 8.7 & 8.5 & 8.1 & -1.5 \\
Belarus (developers),\% & 14.6 & 14.2 & 14.0 & 13.8 & 13.8 & 13.7 & -0.9 \\
Including motor transport,\% & 10.6 & 10.0 & 9.7 & 9.5 & 9.4 & 9.2 & -1.4 \\
Belarus (implemented),\% & 16.8 & 16.6 & 16.4 & 16.3 & 15.7 & 15.4 & -1.4 \\
Including motor transport,\% & 12.1 & 11.5 & 11.2 & 10.9 & 10.8 & 10.6 & -1.5 \\
Kazakhstan (developers),\% & 4.8 & 4.0 & 8.0 & 8.1 & 9.3 & 9.6 & 4.8 \\
Including motor transport,\% & 4.0 & 3.9 & 3.8 & 3.8 & 3.7 & 3.6 & -0.4 \\
Kazakhstan (implemented),\% & 6.1 & 6.0 & 7.7 & 7.8 & 9.0 & 10.1 & 4 \\
Including motor transport,\% & 4.2 & 3.9 & 3.9 & 3.7 & 3.6 & 3.5 & -0.7 \\
\hline *- Compiled by the author on the basis of State Statistics Service of Ukraine (2019), Federal State Statistics Service of the Russian Federa- \\
tion (2019), National Statistical Committee of the Republic of Belarus (2019), Committee on Statistics of the Republic of Kazakhstan (2019)
\end{tabular}

An assessment of the dynamics of the share of enterprises that developed and implemented innovations in key countries of the post-Soviet economic space during the study period showed:

- only in Ukraine and Kazakhstan there was an increase in the share of enterprises - developers of innovations in $2007-2017$ by $2 \%$ and $4.8 \%$, respectively. While in the Russian Federation and Belarus, the share of enterprises - developers of innovations over the study period decreased by $0.1 \%$ and $0.9 \%$, respectively. In none of the selected countries, the share of innovative enterprises exceeded $20 \%$ in $2007-$ 2017, reaching 16.2\% in Ukraine at the end of 2017 (the maximum share among the key countries of the post-Soviet economic space) and 9.3\% in Russia (the minimum share among the key countries of the post-Soviet economic space);

- in relation to motor transport enterprises, the share of economic entities - developers of innovations in this sector decreased over the study period in all selected countries: in Ukraine - by $2.3 \%$ and at the end of 2017 and amounted to $9.1 \%$ of all enterprises in the sector; in Russia - by $1.2 \%$ to $6.4 \%$ at the end of 2017 ; in Belarus - by $1.4 \%$ to $9.2 \%$ at the end of 2017 ; in Kazakhstan - by $0.4 \%$ to $3.6 \%$ at the end of 2017. We note the critically small share of motor transport enterprises that have been developing innovations in key countries of the post-Soviet economic space during the study period;

- only in Ukraine and Kazakhstan there was an increase in the share of enterprises that implemented innovations in their financial and economic activities in $2007-2017$ by $2.8 \%$ and $4.0 \%$, respectively. While in the Russian Federation and Belarus the share of enterprises that implemented innovations during the study period decreased by $1.9 \%$ and $1.4 \%$, respectively. In none of the selected countries, the share of enterprises that implemented innovations in 2007-2017 exceeded $20 \%$, reaching $15.4 \%$ in Belarus at the end of 2017 (the maximum share among key countries in the post-Soviet economic space) and 9.3\% in Russia (the minimum share among the key countries of the post-Soviet economic space); 
- regarding motor transport enterprises, the share of business entities that implemented innovations in their financial and economic activities in this sector decreased during the study period in all selected countries: in Ukraine - by $1.6 \%$ and at the end of 2017 and amounted to $8.6 \%$ of all enterprises of the sector; in Russia - by $1.5 \%$ to $8.1 \%$ at the end of 2017 ; in Belarus - by $1.5 \%$ to $10.6 \%$ at the end of 2017 ; in Kazakhstan - by $0.7 \%$ to $3.5 \%$ at the end of 2017 . We note the critically small share of motor transport enterprises that were engaged in implementing innovations in key countries of the post-Soviet economic space during the study period, where special problems exist in the Russian Federation and Kazakhstan.

Revealing the innovative activity of motor transport enterprises in the context of ensuring their strategic development, we consider it necessary to assess the directions of the development and implementation of innovations by enterprises of this sector of national economies in key countries of the post-Soviet economic space (Table 2). At the same time, given the complexity of interpreting such information, we will use the following designations in the table as an assessment: "+++" - very often developed and implemented in financial and economic activities; "++" - not often developed and implemented in financial and economic activities; "+" - extremely rarely developed and implemented in financial and economic activities.

\section{Table 2}

Assessment of directions for the development and implementation of innovations in motor transport enterprises in key countries of the post-Soviet economic space

\begin{tabular}{|c|c|c|c|c|}
\hline $\begin{array}{l}\text { Directions for the development and } \\
\text { implementation of innovations }\end{array}$ & Ukraine & Russia & Belarus & Kazakhstan \\
\hline Engineering & ++ & ++ & ++ & ++ \\
\hline Technologies & + & + & + & + \\
\hline Management & ++ & ++ & + & + \\
\hline Industrial sphere & + & + & + & + \\
\hline Product shpere & ++ & + & + & ++ \\
\hline Personnel management & + & + & + & + \\
\hline Marketing & ++ & ++ & ++ & ++ \\
\hline Social sphere & + & + & + & + \\
\hline
\end{tabular}

Based on this assessment, we can conclude that none of the areas of development and implementation of innovations was a priority for motor transport enterprises in Ukraine, Russia, Belarus and Kazakhstan. At the same time, the innovative activity of enterprises in this sector of the economy in the countries selected for the study was higher in the following directions: engineering - through the purchase of innovative equipment abroad, and marketing - through the use of foreign and own developments. In Ukraine and Russia, a certain emphasis in innovative developments and implementation of innovations was placed on the management direction.

Thus, the study indicates that there are significant problems with the innovative activity of motor transport enterprises in Ukraine, Russia, Belarus and Kazakhstan and insufficient stimulation of the development, sale, purchase and implementation of innovations by these enterprises.

\subsection{The Issue of Stimulating Innovative Activity of Motor Transport Enterprises}

Insufficient innovation activity of business entities in key countries of the post-Soviet economic space, especially as regards motor transport enterprises that was identified earlier, is one of the roots of problems in the strategic development of such business entities and negatively affects their competitiveness (see Fig. 5). In this case, the main thing, in increasing the innovative activity of motor transport enterprises, should be an appropriate stimulation of this activity of business entities. Insufficient innovative activity in this sector of the transport industry of the economy of the states selected for the study requires the identification of problems that hinder the optimization of such activities.

We consider it necessary to divide all the problems of stimulating innovative activity of motor transport 
enterprises in key countries of the post-Soviet economic space into three groups: problems at the macrolevel; problems at the meso-level; problems at the micro-level.

We attribute the problems of stimulating innovative activity of motor transport enterprises in Ukraine, Russia, Belarus and Kazakhstan at the macro level to the problems at the level of state and municipal authorities, namely:

- inefficient state system of support and development of innovative activity in the countries selected for research, which include many inefficient institutions that perform their functions formally;

- inefficient legislative support for innovative activity of enterprises, including motor transport, where the tools for encouraging such activity are not determined;

- low qualification of employees of state and municipal authorities, designed to stimulate state and regional support for innovative activity of enterprises, including in the provision of motor transport services;

- insufficient activity of state scientific institutions, including educational ones, in the development and implementation of innovations, as well as interaction with enterprises on innovative developments, especially with regard to motor transport;

- a critically low level of financial incentives for innovative activity of enterprises, including motor transport in the area of both taxation and financing or co-financing the development, purchase and implementation of innovations (Table 3).

\section{Table 3}

Dynamics of the state's share in financing the development, purchase and implementation of innovations by enterprises in key countries of the post-Soviet economic space in 2007-2017 (including motor transport enterprises)

\begin{tabular}{|c|c|c|c|c|c|c|c|}
\hline Country & 2007 & 2009 & 2013 & 2015 & 2016 & 2017 & Deviation \\
\hline Ukraine, $\%$ & 1.3 & 1.6 & 0.26 & 0.40 & 0.77 & 2.79 & 1.49 \\
\hline Including motor transport, $\%$ & 0.6 & 0.3 & 0.1 & 0.1 & 0.2 & 0.5 & -0.10 \\
\hline Russia, \% & 5.2 & 5.0 & 5.1 & 5.3 & 5.4 & 5.5 & 0.30 \\
\hline Including motor transport, $\%$ & 1.1 & 1.0 & 0.9 & 0.8 & 0.7 & 0.9 & -0.20 \\
\hline Belarus, $\%$ & 6.3 & 5.5 & 6.1 & 6.1 & 6.0 & 6.0 & -0.30 \\
\hline Including motor transport, $\%$ & 1.4 & 1.2 & 1.1 & 1.2 & 1.1 & 1.3 & -0.10 \\
\hline Kazakstan, \% & 0.8 & 0.7 & 1.2 & 1.4 & 1.6 & 1.9 & 1.10 \\
\hline Including motor transport, $\%$ & 0.1 & 0.1 & 0.2 & 0.2 & 0.2 & 0.4 & 0.30 \\
\hline
\end{tabular}

*- Compiled by the author on the basis of State Statistics Service of Ukraine (2019), Federal State Statistics Service of the Russian Federation (2019), National Statistical Committee of the Republic of Belarus (2019), Committee on Statistics of the Republic of Kazakhstan (2019)

The problems of stimulating innovative activity of motor transport enterprises in key countries of the post-Soviet economic space at the meso-level are problems at the level of individual enterprises, which include:

- low level of financial resources allocated for the development, purchase and implementation of innovations, due to the size of enterprises;

- the interest of owners of business entities in obtaining the maximum benefit in the short term and reluctance to withdraw financial resources of motor transport enterprises and direct them to innovative activity;

- making enterprise management busy with current problems and the inability to pay attention to the issues of its strategic development, including the innovative activities;

- lack of special staff or subdivisions that deal with the development, purchase and implementation of innovations;

- lack of material and non-material incentives for employees of enterprises regarding the development of innovative products and solutions. 
The problems of stimulating innovative activity of enterprises providing motor transport services in Ukraine, Russia, Belarus and Kazakhstan at the micro-level are problems at the level of individual employees of such business entities, where we can distinguish the following:

- lack of understanding by employees of enterprises of the importance of innovation for the activity of both the business entity and the employees themselves;

- low level of professional training in the field of innovation and unwillingness to increase it;

- lack of material and time reserves for the implementation of innovation activities due to making busy with operating activities;

- critically low level of loyalty to the enterprise, its owners and management.

\subsection{Ways to optimize the stimulation of innovative activity of motor transport enterprises in ensuring their strategic development}

A significant number of problems at the macro-, meso-, and micro-levels requires finding ways to optimize incentives for innovative activities of motor transport enterprises in key countries of the post-Soviet economic space in the context of ensuring their strategic development and ensuring or improving competitiveness in domestic and foreign markets of motor transport services. It is proposed to use a set of optimization paths, where:

- at the macro-level, emphasis should be placed on: increasing the efficiency of the use of state and municipal funds; development of partnerships between state and municipal authorities, as well as representatives of motor transport enterprises; the creation of clusters of incentives for innovation, which will include state and municipal authorities, representatives of state research organizations, educational institutions (mainly universities), representatives of banking and investment capital, representatives of motor transport and other enterprises;

- at the meso-level, motor transport enterprises need to follow the path of: cooperation to solve the problems of insufficient financing for the development, purchase and implementation of innovations; clear regulation of managerial functions among managerial staff to enhance the strategic aspects of enterprise management and stimulate their innovative activity; training personnel in the field of innovative developments and their implementation to enhance their innovative activity; development of a clear system of material and non-material incentives with a focus on the latter group of incentives to increase innovative activity of the personnel; adjusting the selection criteria and personnel training with a focus on their innovative activities; increasing employee loyalty to the enterprise, its owners and managers;

- at the micro-level, the ways to solve the problems of stimulating innovative activity in motor transport enterprises are: enhancing professional training with an emphasis on innovative developments; focus on seeking incentives for innovative activity and the development of self-stimulation of employees.

Considering ways to optimize incentives for innovative activities of motor transport enterprises in ensuring their strategic development, it is necessary to understand that there are many alternatives, but given the limited resources of business entities that provide motor transport services, it is necessary to select them correctly with the help of calculation of the effectiveness of using incentives (E):

$$
\mathrm{E}_{\text {sia }}=\sum_{\mathrm{i}=1}^{\mathrm{n}}\left(B_{m i}+B_{\text {ini }}\right) \div \sum_{\mathrm{j}=1}^{\mathrm{m}} \mathrm{C}_{j}
$$

where $E_{\text {sia }}$ - efficiency of the use of a particular way to stimulate innovative activity of a motor transport enterprise; $B_{m i}$ - material benefits from the stimulation of innovative activity, nominated in monetary units; $B_{i n i}$ - non-material benefits from the stimulation of innovative activity, nominated in monetary units; $\mathrm{C}_{j}$ - cost of stimulating innovative activity, nominated in monetary units; $i$ - number of benefits obtained from the stimulation of innovative activity of an enterprise (from 1 to $n$ ); $j$ - amount of expenses incurred by an enterprise in the process of stimulating innovative activity (from 1 to $m$ ). 
It should be noted that the use of the chosen path to stimulate innovative activity of a motor transport enterprise would be appropriate only if the inequality is observed:

$$
\mathrm{E}_{\text {sia }}>1 \text {, }
$$

It should be noted that a motor transport enterprise can use not one, but a whole system of ways to stimulate innovative activity, in this case the above formula should be transformed in order to calculate the efficiency of using the whole system of incentives, taking into account the synergy effect of their joint use. If there is a need to choose the optimal system of incentives from a certain number of alternative ways of stimulation, it would be necessary to use cost constraints (if any costs are involved) and choose such a system that provides the maximum ratio of benefits and expenses.

\section{Discussion}

The strategic development of an enterprise is the basis of its long-term successful operation in the domestic and foreign markets, as well as a key to achieve a sufficient level of competitiveness or increase this level. In this case, innovative activity of business entities is an important tool for this development. This can be fully attributed to motor transport enterprises in Ukraine, Russia, Belarus and Kazakhstan.

It should be noted that the assessment of the development of the transport industry and its road transport sector in the countries of the post-Soviet economic space in 2007-2017 revealed the significant importance of transport and motor transport for the economies of these countries, where the motor transport sector is actively developing, especially in Ukraine and Kazakhstan, despite the crisis of the transport industry. We note the specifics of the motor transport sector in the countries selected for research, where most enterprises belong to small or medium-sized businesses and large enterprises account for less than $0.1 \%$ of all enterprises in the sector, while in other sectors of the transport industry large enterprises or enterprises-monopolists dominate (rail transportation). The foregoing indicates that the first hypothesis put forward at the beginning of the study is not fully proved.

The graphical interpretation of the formation and ensuring strategic development of a motor transport enterprise presented in the work allows us to prove the interdependence of this development and innovative activity. At the same time, it can be noted that innovation activity is one of the main tools for ensuring effective strategic development of motor transport enterprises, including in the countries selected for research, which fully proves the hypothesis put forward at the beginning of work.

We note the lack of effective incentives and a built incentive system for innovative activity of motor transport enterprises in Ukraine, Russia, Belarus and Kazakhstan, as well as a large number of problems with stimulating such activity in the motor transport sector of key countries of the post-Soviet economic space, which allows us to prove the third hypothesis of the study.

The developed set of ways to optimize the stimulation of innovative activity of Ukrainian, Russian, Belarusian, Kazakhstani motor transport enterprises in ensuring their strategic development, together with the use of the developed mathematical tools, proves the fourth hypothesis of this research paper.

Given the above, we can note that the objective of this study, which was set at the beginning of the work, is achieved. The key value of the research paper is: the identified relationship between the strategic development of motor transport enterprises and their innovative activity; localization of the problems of stimulating innovation activity by road transport enterprises of Ukraine, Russia, Belarus and Kazakhstan in ensuring their strategic development; developed set of ways to optimize the stimulation of innovative activity of Ukrainian, Russian, Belarusian, Kazakhstan motor transport enterprises in ensuring their strategic development. In this regard, it is possible to identify some restrictions on the application of the results of this research paper, namely: the need to rework the mathematical tools for assessing the effectiveness of using a set of ways to stimulate innovative activity of a motor transport enterprise; the need for detailed elaboration of ways to stimulate innovative activity of motor transport enterprises taking into account the peculiarities of the functioning of the economies of each of the states selected for research. At the same time, the formulated restrictions do not reduce the scientific and practical value of this research paper and describe, to a greater extent, the prospects for further research. 


\section{Conclusions}

The transport industry and its motor transport sector are crucial for any country in the world. For the key countries of the post-Soviet economic space, it is the increase in the efficiency of motor transport enterprises that is a key to stable development of national economies in the conditions of a crisis of the transport industry and the growing importance of motor transport in the face of increasing exports of products of the agro-industrial complex, mainly grain and oilseeds. In this situation, there is an increasing need for strategic management and ensuring the effective strategic development of the said enterprises in the countries selected for the study, which is impossible to achieve without stimulating the innovative activity of business entities that provide motor transport services. This study allows us to more clearly reveal the features of the strategic development and innovation activity of motor transport enterprises of Ukraine, Russia, Belarus and Kazakhstan, identify key problems of stimulating innovative activity of the said enterprises in ensuring their effective strategic development, as well as develop ways to solve the identified problems. The practical implementation of the proposals and conclusions of this research paper should be considered in the context of their importance for improving the efficiency of strategic development and innovative activity of motor transport enterprises in key countries of the post-Soviet economic space. Prospects for further development based on the scientific results of this study are as follows: expanding the mathematical tools for assessing the effectiveness of using a separate path, a set of paths, alternative ways of stimulating innovative activity of a motor transport enterprise; detailing the problems and ways to solve them regarding the stimulation of innovative activity of motor transport enterprises in each of the countries selected for the study.

\section{References}

Adanikin, A., \& Oyedepo, J. (2017). Public transport policy in developing countries: Nigeria as a case study. 1st International Conference of the School of Management Technology (SMAT) Federal University of Technology (pp. 21-37). Akure.

Aggelakakis, A., Bernandino, J., Boile, M., Christidis, P., Condeco, A., Krail, M., Papanikolaou, A., Reichenbach, M., \& Schippl, J. (2015). The Future of the Transport Industry. Available at http://publications.jrc.ec.europa.eu/repository/bitstream/JRC93544/future\%20of\%20tansport $\% 20$ ind ustry\%20report\%20final3.pdf

Borgström, B., Gammelgaard, B., \& Wieland, A. (2017). Strategic themes in the haulier business: A systematic literature review of road freight transport. Available at https://openarchive.cbs.dk/bitstream/handle/10398/9518/Borgstroem_Gammelgaard_Wieland_nofo ma2017.pdf?sequence $=1$

Chuvaev, P. I. (2013). Problems and prospects of development of motor transport of Ukraine. Sevastopol National Technical University Bulletin. Series: Machinery Building and Transport, 143, 196-198.

European Commission. (2011). Roadmap to a Single European Transport Area - Towards a competitive and resource efficient transport system. Available at https://eurlex.europa.eu/LexUriServ/LexUriServ.do?uri=COM:2011:0144:FIN:en:PDF.

Committee on Statistics of the Republic of Kazakhstan. (2019). Statistical information. Available at http://stat.gov.kz.

Condeço-Melhorado, A., Vieira, J., Krail, M., Reichenbach, M., \& Schippl, J. (2013). The European innovation system in transport and current state of the competitiveness of the EU transport sector. http://www.futre.eu/Portals/0/Documents/Deliverables/Deliverable\%202.1 The\%20EU\%20innovation\%20systems\%20 and $\% 20$ the $\% 20$ current $\% 20$ state $\% 20$ of $\% 20$ the $\% 20$ competitiveness $\% 20$ of $\% 20$ the $\% 20 \mathrm{EU} \% 20$ transport $\% 20$ sector.pdf

European Commission. (2012). Road Transport. A change of gear. Luxembourg: Publications Office of the European Union.

Faylert, A.A. (2016). Development of road transport in Russia and abroad. Theory and Practice of Modern Science, 8(14), 364-369.

Federal State Statistics Service of the Russian Federation. (2019). Statistical information. Available at http://www.gks.ru.

Zheleznyak, K. L. (2012). Motor transport enterprise strategy selection, as a part of fragmentary industry. The National Transport University Bulletin: A Scientific and Technical Journal, 26(2), 147-150. 
Halunko, V., Chyzhmar, I., \& Kurkova, K. (2018). Modern mechanism of strengthening innovative activity of transport enterprises. Baltic Journal of Economic Studies, 3, 33-41.

Kim, V. V. (2016). Features of the transport sector in the Republic of Kazakhstan. Young Scientist, 5(5), 11-14.

Kulakova, S., Boldyrieva, L. M., Amelina, I. V., \& Goloborodko, A. P. (2018). Strategic management by enterprise's transport potential. International Journal of Engineering \& Technology, 7(4.8), 613617.

Leinbach, T. R. (1995). Transport and third world development: review, issues, and prescription. Transportation Research Part A: Policy and Practice, 5, 337-344.

Lendel, V., Hittmár, Š., \& Latka, M. (2015). Application of management of innovation processes in enterprises: management approach, problems and recommendations. Procedia Economics and Finance, 34, 410-416.

Loo, B., \& Tsoi, K. H. (2018). The sustainable transport pathway: A holistic strategy of Five Transformations. Journal of Transport and Land Use, 1, 961-980.

Luzhetskyy, V. (2016). Innovative activities of motor transport enterprises. In: Materials of International scientific and practicial conference: The scientifc potential of the present (pp. 136-138). St Andrews, Scotland, UK.

Moen, O. (2016). The five-step model-procurement to increase transport efficiency for an urban distribution of goods. Transportation Research Procedia, 12, 861-873.

National Statistical Committee of the Republic of Belarus. (2019). Statistical information. Available at http://www.belstat.gov.by.

OECD. (2019). Innovation activities. Glossary of statistical terms. Available at https://stats.oecd.org/glossary/detail.asp?ID=6863.

Pettigrew, A., Thomas, H., \& Whittington, R. (2002). Strategic Management: The strengths and limitations of a field. In: Handbook of strategy and management (pp. 3-30). London: SAGE.

Porter, M. E. (1997). Competitive strategy. Measuring Business Excellence, 1(2), 12-17.

Synytsia, L.V. (2015). Formation of a system of transport company's strategic management, based on its innovative activity's valuation. Economics: Time Realities, 4(20), 267-271.

State Statistics Service of Ukraine. (2019). Statistical information. Available at http://www.ukrstat.gov.ua.

Sukhonos, N. I. (2012). Transport Complex of the Republic of Belarus and Transit Potential: State, Development and Perspectives. Brest State A. S. Pushkin University Bulletin. Series 2, 1, 96-102.

Thor, S. O. (2013). Prospects of development of the transport complex of Ukraine. Investytsiyi: praktyka ta dosvid, 1, 54-56.

Tkachev, O. G. (2017). Transport of Russian Federation: Problems and Trend of Its Development. $\mathrm{Ad}$ ministrative Consulting, 6, 183-189.

Toymentseva, I.A. (2012). Complex assessment of efficiency of strategy of development of the motor transportation enterprises with application of economic-mathematical methods. The Bryansk State University Herald, 3(2), 151-157.

Tsymbal, S. V. (2014). Development method of selection strategy ground transportation. The Journal Of Zhytomyr State Technological University. Series: Engineering, 2(69), 198-203.

Wiesenthal, T., Leduc, G., Cazzola, P., Schade, W., \& Köhler, J. (2011). Mapping innovation in the European transport sector. Seville: European Commission.

Zohrehvandi, S., \& Ghazanfari, H. (2013). Role of strategic planning in transportation management to improve the performance of transportation company. International journal of business tourism applied sciences, 5, 33-51.

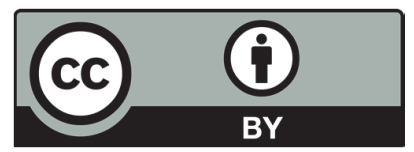

(C) 2019 by the authors; licensee Growing Science, Canada. This is an open access article distributed under the terms and conditions of the Creative Commons Attribution (CCBY) license (http://creativecommons.org/licenses/by/4.0/). 